InOedia $\quad \begin{aligned} & \text { InMedia } \\ & \text { The French Journal of Media Studies }\end{aligned}$

8.1. 2020

Ubiquitous Visuality

A Portrait of a 'Selfie' in the Making

An Iconological Analysis of Roberto Schmidt's Photograph of Three

World Leaders Taking a Selfie

\title{
Béatrice Trotignon
}

\section{Q OpenEdition \\ 1 Journals}

\section{Electronic version}

URL: http://journals.openedition.org/inmedia/2183

DOI: 10.4000/inmedia.2183

ISSN: 2259-4728

\section{Publisher}

Center for Research on the English-Speaking World (CREW)

\section{Electronic reference}

Béatrice Trotignon, "A Portrait of a 'Selfie' in the Making", InMedia [Online], 8.1. | 2020, Online since 15 December 2020, connection on 05 February 2021. URL: http://journals.openedition.org/inmedia/2183 ; DOI: https://doi.org/10.4000/inmedia.2183

This text was automatically generated on 5 February 2021.

(c) InMedia 


\title{
A Portrait of a 'Selfie' in the Making
}

\author{
An Iconological Analysis of Roberto Schmidt's Photograph of Three \\ World Leaders Taking a Selfie
}

Béatrice Trotignon

1 During Nelson Mandela's memorial service on December 10th, 2013, at the First National Bank Stadium in Soweto, Agence France Presse South Asia photo chief Roberto Schmidt took a photograph of Danish Prime Minister Helle Thorning-Schmidt making a selfie with U.S. President Barack Obama and U.K. Prime Minister David Cameron. The image tweeted by the AFP newswire went viral and spurred an intense debate internationally in the media ${ }^{1}$ on the use and misuse of selfies, soon nicknamed Selfiegate. Breaking away from "discourses of pathology" favored by many news articles on the general phenomenon of selfies, academic approaches have emerged, studying selfies through the lenses of information and communications studies, cultural studies, digital humanities, sociology of social practices, and aesthetics. Codirecting a special section of the International Journal of Communication (2015) under the banner "Studying Selfies," Nancy K. Baym, focused with Kate M. Miltner on the American, British and Danish news coverage of the "Selfiegate" in "The Selfie of the Year of the Selfie: Reflections on a Media Scandal." Their analysis of the news media discourse $^{3}$ shaping the scandal and moral-cum-technological panic sparked by the event uncovered lingering race and gender biases as well as multiple cultural shifts and anxieties about technology, leadership, changing social mores and norms, or the evolution of journalism in the age of social media.

2 Little, however, has been said about the iconology of this photograph itself, which is the main focus of the present paper, showing how its compositional strength and visual power rests in the way it contains a lexicon of portraiture and gazes, ranging from the Renaissance female profile portrait to the front-faced memorial portrait and the latest fashion of selfies. The growing use of the latter by politicians, arguably drawing the selfie away from its originally private, self-reflective status, will lead to comments on Obama's use of selfies in his communication strategy. The final part will go back on the topic of gazes in selfies per se. 


\section{This is Not a Selfie}

3 Roberto Schmidt's photograph was dubbed "The Obama Selfie" in most news articles. First, we should keep in mind, as Milner and Baym also have, that this so-much-debated picture is not a selfie- the characteristics of which will be mentioned later in the paper-, but a photograph of the act of taking a selfie, shot by a professional photographer, AFP South Asia photo chief Roberto Schmidt, who was doing his job covering Nelson Mandela's memorial. ${ }^{4}$ More than 500 photographs taken by many photojournalists attending the event were published on that day, but only one of Roberto Schmidt's photographs would be given so much attention and remembered as “The Obama Selfie." Here it is, in its full size, as published on Schmidt's AFP blog page:

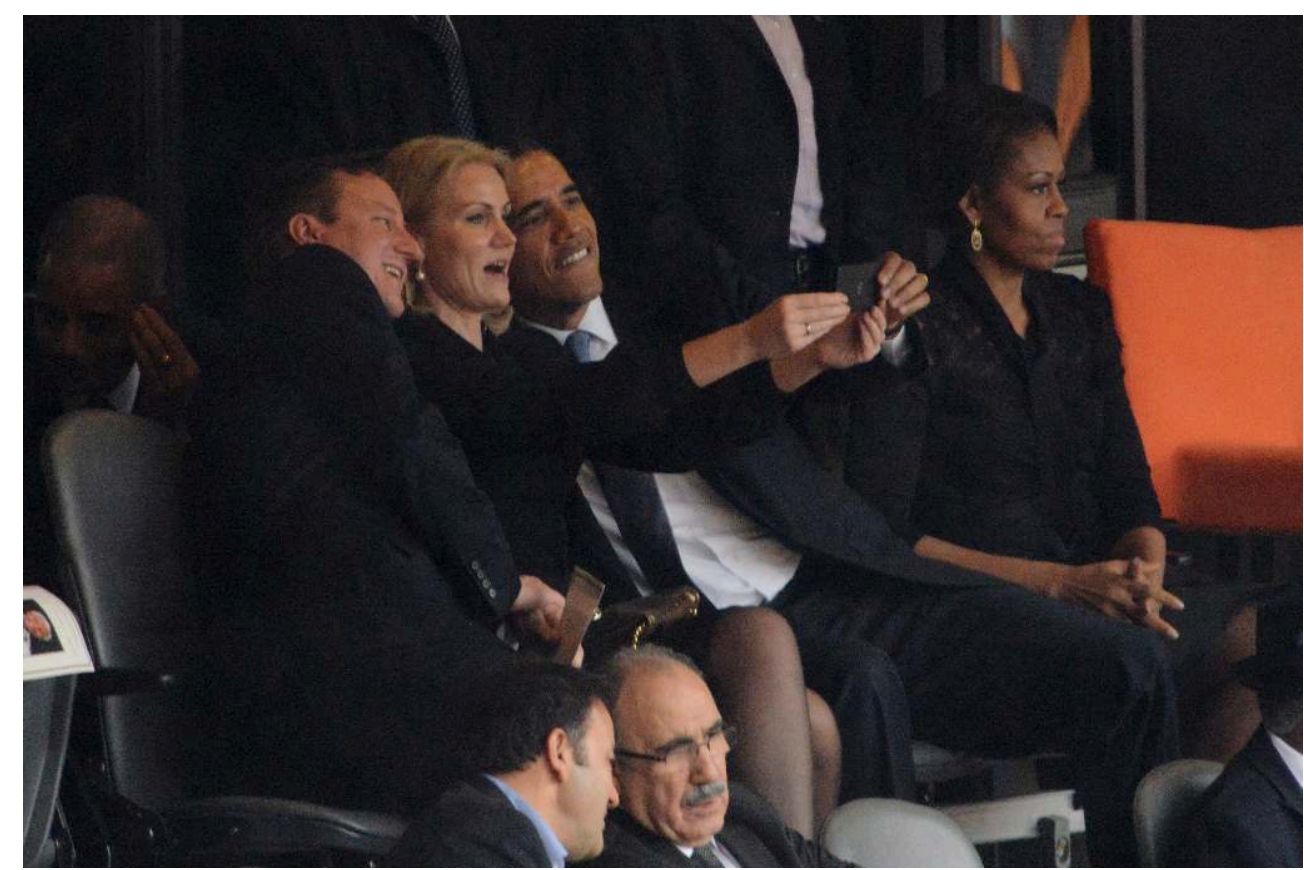

Fig. 1: Roberto Schmidt, Agence France Presse (@ AFP)

The other two pictures Schmidt adds along give an idea of the many various, step-bystep shots he took in the process ${ }^{5}$, somewhat deflating the notion the picture might have captured a "decisive moment." Schmidt's AFP blog also includes the front pages of some of the newspapers (Mail Online, The Times, Sun+, The Financial Times, The Telegraph) that commented on the event and pictures: most of them cut off parts of Schmidt's photographs. Why not? After all, they were not interested in their iconology or aesthetics. Only the fascination about what the pictures might say of our times mattered.

\section{Reading the image iconologically}

5 Yet, when considered in its full size, the so-called "Obama selfie" carefully built from an iconographic and iconological perspective, accounting for some of its power on the viewer and its selection among all the others as the one delivering "the definitive summation" of the event. This photograph carries not only a referential function as press photographs generally do, but also an expressive one which, as Martine Joly 
reminds us, is also a specific function of press photographs. ${ }^{6}$ She also argues that the press photograph actually fosters contemplation through its rhetoric and aesthetic form, ${ }^{7}$ whether these criteria are deliberate or not on the part of the photographer.

In Schmidt's photograph, specific compositional elements do feed contemplation and visual pleasure. Not surprisingly, the common rule of thirds, making for a balanced composition $^{8}$, is used, placing the Danish prime minister's smartphone and the trio's heads at strategic focal points:

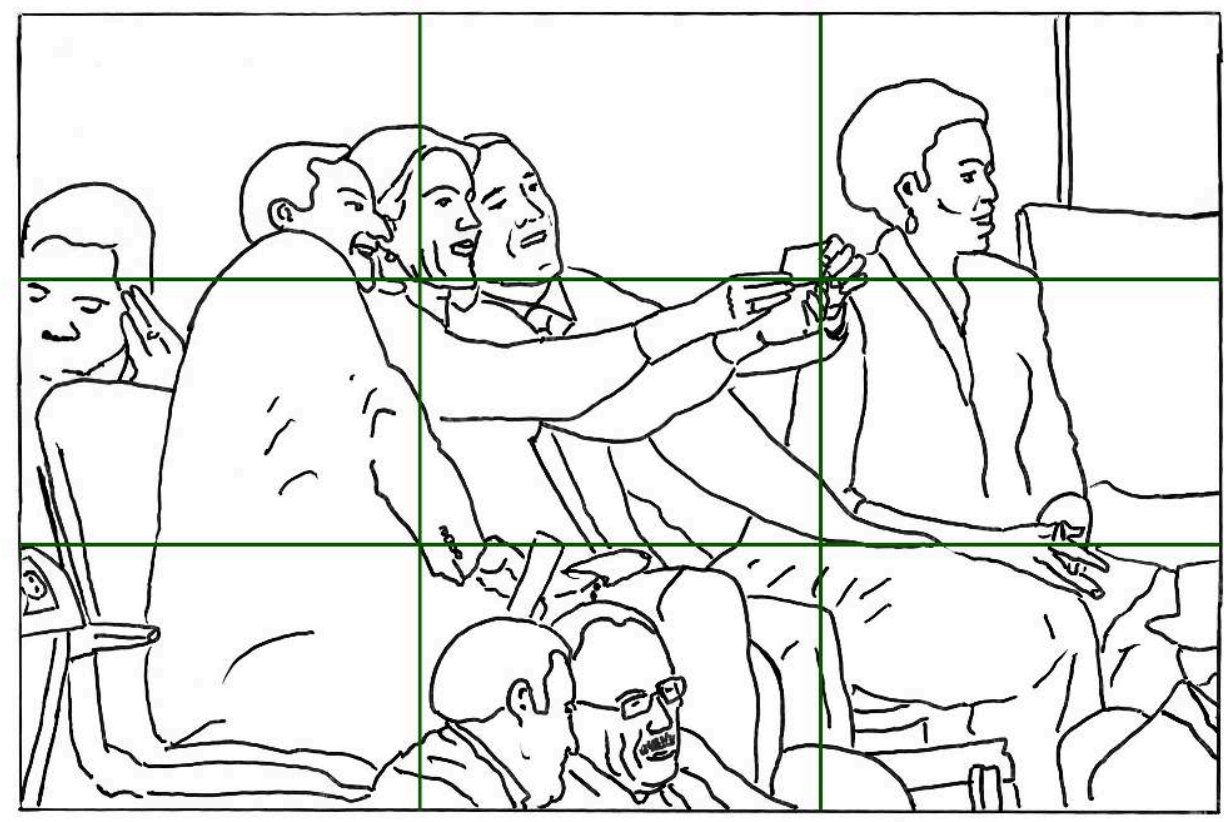

Fig. 2 (My own tracing based on Roberto Schmidt's photograph)

7 Michelle Obama's and David Cameron's heads and Michelle Obama's hands are also strategically placed within their own rectangles on the top right and top left (with the rule of third applied) and on the bottom right. The diagonals of the photograph also run across their faces and one of the diagonals is parallel to the Danish prime minister's extended arms, which lead towards Michelle Obama's face. 


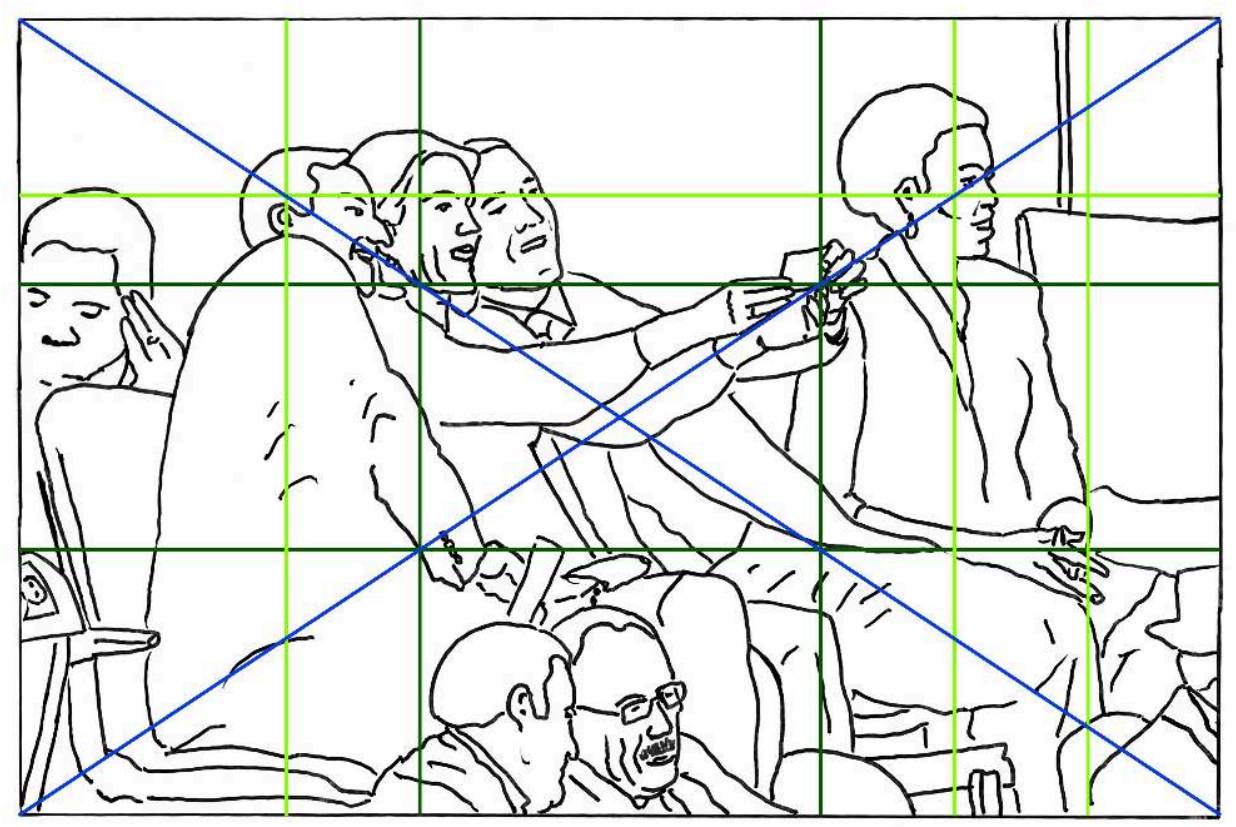

Fig. 3

Further analysis of the various lines, circles and triangles (cf. Fig. 4) within the photograph reveals a composition that complies with some of the basic rules for wellbalanced pictures. This is not only due to the photographer's know-how, but also because the scene is set within a space that is, in itself, highly geometric, with the ceremony taking place at the Soccer City Stadium, in which its dark grey and mostly orange seats are regularly spaced. The equal distance between the seated watchers along and between the rows are architecturally predetermined, while the human body itself is also built on regular proportions.

There are nevertheless a number of unpredictable, chance elements that heighten the strength of the composition, and could indeed make it worthy of another nickname given to it by art critic journalist Jerry Saltz in his Vulture article on the history of the selfie: “This was a kind of Las Meninas selfie-akin to Velázquez's astonishing royalportrait-plus-self-portrait, which ricochets among the subjects, switching up who's seeing whom from where." Unfortunately, Saltz's inclusion of Schmidt's photograph in his article is yet another cropped version of it. But his hunch about the whole photograph's iconological value in terms of classical portraiture, hidden images and ricocheting gazes is worth exploring.

\section{From Classical Portraiture to Selfies and Front-Faced Portraits}

10 As mentioned earlier, hundreds of photographs of these world leaders were taken during the memorial, but a single one captured media attention. As Baym and Miltner showed, the gazes directed at the picture and the discourse that articulated them revealed a number of social norms and cultural anxieties, among which the differing traditions of memorialization, the norms of managing emotional expression and the generally negative connotation surrounding selfie-taking, seen as an anti-social act, or 
a "juvenile, frivolous and narcissistic"10 gesture, not expected on the part of world leaders attending an official ceremony. ${ }^{11}$ Baym and Miltner also listed many instances of racist and sexist narratives, making for "the infantilizing of Obama, the portrayal of Michelle Obama as an angry Black woman, and illicit sexual attraction between a Black man (Obama) and a White woman (Thorning- Schmidt)." ${ }^{12}$

But on the AFP blog, Roberto Schmidt, briefly broaching the theme of the official portraiture of political leaders, underlined that the atmosphere during the four-hour long celebration was relaxed and joyful, more akin to an African-style festival than a morbid, melancholy ceremony. In this context, he felt the world leaders, snapping away pictures as they were, were simply acting like regular human beings. ${ }^{13}$

He also undermined the general "Selfiegate" narrative, which claimed Michelle Obama was upset that her husband was "misbehaving"."In reality, just a few seconds earlier the first lady was herself joking with those around her, [British Prime Minister David Cameron and Danish Prime Minister Helle Thorning-Schmidt] included," the photographer writes. "Her stern look was captured by chance." ${ }^{14}$

Michelle Obama's pose is interesting to notice not so much from a psychological or moral perspective but rather from a visual and iconographic one, with a focus on its underlying iconographic lexicon. Her pose is strikingly reminiscent of the dominant codes of $14^{\text {th }}$ and $15^{\text {th }}$ century Italian Renaissance female portraiture, and conforms to a number of its recognizable constituent elements ${ }^{15}$ such as a deadpan profile, a straight upper body, clasped hands resting on knees, a monochrome background with or without colored draperies and eyes fixedly gazing towards an out-of-frame focal point. At that time, profile portraiture was mostly used for donor portraits, and the pose stemmed from a renewed interest in engraved medals and coins ${ }^{16}$ from the Antiquity. What's more, it was a preferred pose for women as it was associated to virtue ${ }^{17}$, adding moral strata to the visual code. Through her isolated profile, traditionally connoting virtue, Michelle Obama appears to bear an appropriate demeanour with her gaze directed towards an out-of-frame space which we know is the celebration of deceased Mandela. And taken on its own, her pose, evocative as it is of traditional portraits, reactivates their link to death and transcendence, ${ }^{18}$ fueling the notion her pose is dignified. ${ }^{19}$

14 Michelle Obama's figure contrasts first with a group of two men, seated below, in the bottom foreground. Their faces are inwardly turned as they chat away together, the way mere bystanders commonly do on the margin of a bigger event. Their pose evokes a universally human attitude, one also often captured in many classical paintings depicting crowd attendees at important events, such as the Adoration of the Magi for instance in works by Gentile da Fabriano or Sandro Botticelli. ${ }^{20}$

Michelle Obama's singular deadpan figure contrasts more blatantly still with the smiling trio sitting on her right. All three groups, incrementally increasing in the number of their component figures, are set within a near equilateral triangle, the tip of which falls at the dead center of the bottom line. 


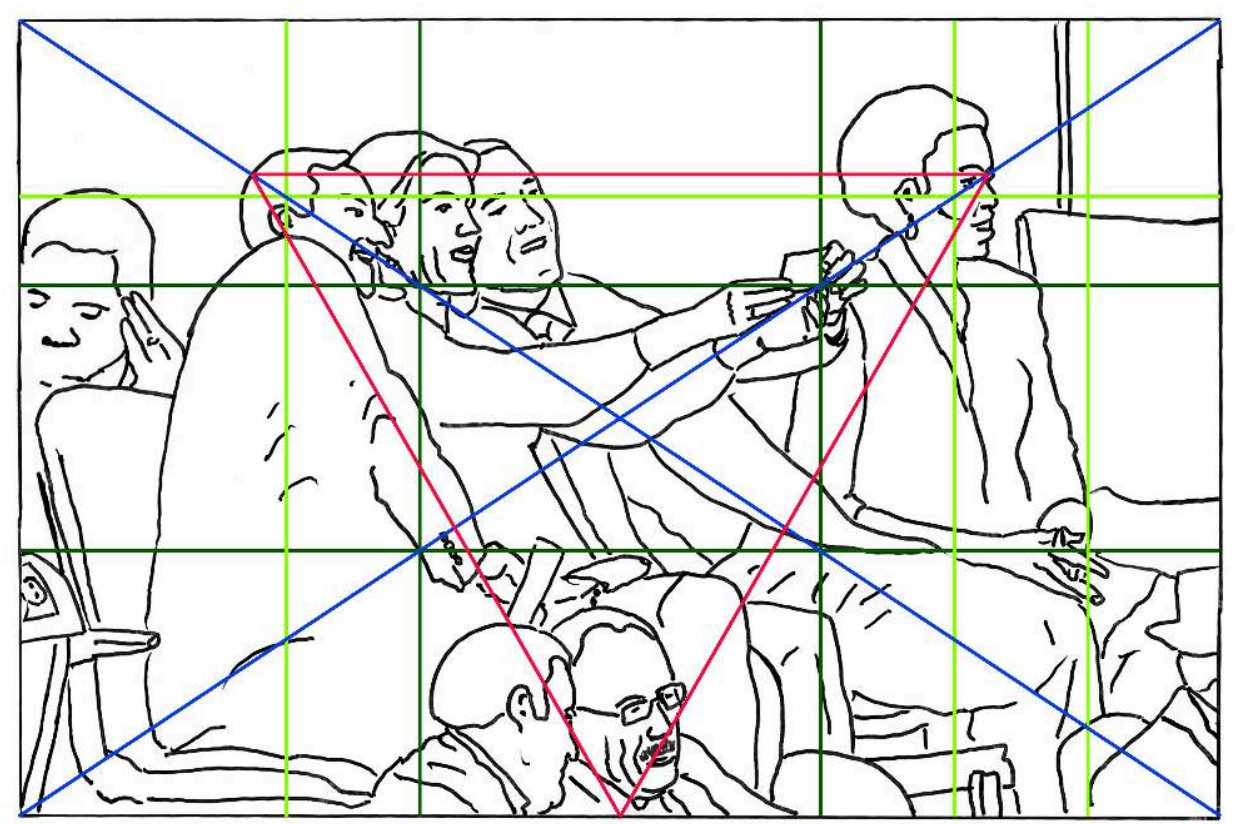

Fig. 4 ducked head behind Cameron) or incomplete (a man's shirt and tie behind Michelle Obama and a Magritte-like bowler-hatted head in the bottom right of the picture). Whether the phasing out of these secondary figures is the result or not of some tweaking on the part of the photographer remains difficult to assess, but the photograph he posted on the AFP blog is one in which three incremental groups do stand out. pointing towards the out-of-frame space, they are in fact concentrating on a much closer focal point, i.e. the smartphone which, in the process of taking their picture, creates a mirroring, inward focal point. ${ }^{21}$ There is an immediate sense of a shrinking, enclosed space whereas Michelle Obama's gaze had been stretching it outwards. 


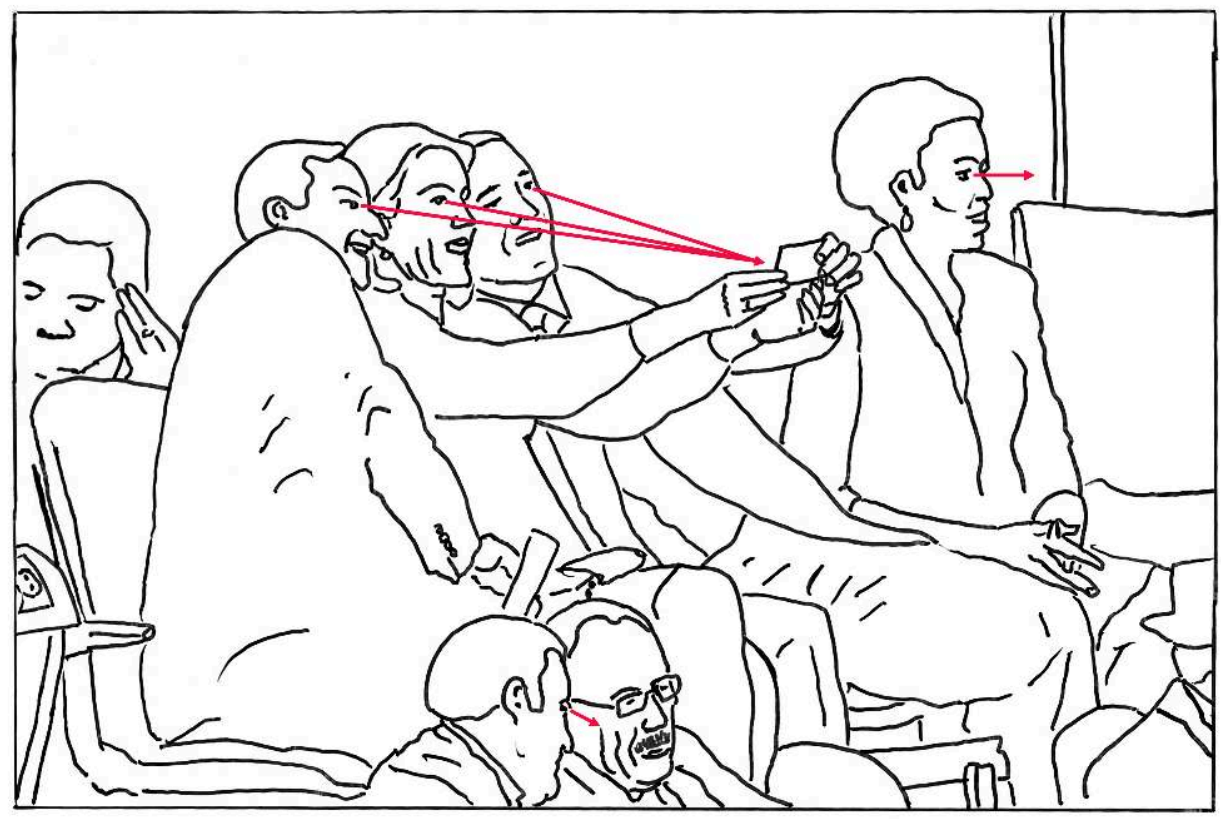

Fig. 5

The trio's body pose bears all the structural characteristics and visual clichés ${ }^{22}$ of selfietaking: the stretched arms holding the smartphone and the heads leaning closer, trying to fit within the frame ${ }^{23}$. As art critic journalist Jerry Saltz has argued in his Vulture article, selfies have become a new visual genre-a type of self-portraiture formally distinct from all others in history. Selfies have their own structural autonomy. This is a very big deal for art." He further adds that it is "a genre that is not dominated by artists," and that "[i]t's possible that the selfie is the most prevalent popular genre ever." ${ }^{24}$

What makes Roberto Schmidt's professional photograph so interesting from an iconological point of view is its meta-photographical nature, however unintentional this surplus of meaning may have been on the part of the taker. In a professionally and aesthetically composed group portrait two highly coded and traditional types of portraits (Michelle Obama and the duo of chatting onlookers) are juxtaposed alongside the new selfie-dictated body posture of the trio (hence another code), using a nonartistic, popular mode of self-portraiture.

What's more, reinforcing the above contrast between different types of portraits, yet another traditional form of portrait lies in the bottom left margin of the photograph (just below one of the compositional lines), a portrait that should be all the more noticed since Schmidt was careful not to crop it away from his photograph when he could easily have done so as other media have. Taking on Barthes's well-known lexicon, this could be considered as another punctum in the photograph on top of Michelle Obama's classical pose. This relevant portrait element is an aptly lying photograph of a smiling, front-faced Mandela, chosen to illustrate the programme of the ceremony devoted to his memory. According to a rhetorical code associated to photographic portraits, as Susan Sontag noted in her essays on photography, front-faced photographs bear a number of qualities:

In the normal rhetoric of the photographic portrait, facing the camera signifies solemnity, frankness, the disclosure of the subject's essence. That is why frontality 
seems right for ceremonial pictures (like weddings, graduations) but less apt for photographs used on billboards to advertise political candidates. (For politicians the three-quarter gaze is more common: a gaze that soars rather than confronts, suggesting instead of the relation to the viewer, to the present, the more ennobling abstract relation to the future. $)^{25}$

The haphazard presence of Mandela's portrait in the bottom left rectangle of the photograph, in the backs of the attendees, creates an interesting tension with Michelle Obama's head, placed in the top right rectangle of the photograph, with her gaze directed towards the out-of-focus ceremony. Deceased Mandela is both present and absent, both inside and outside Schmidt's photograph: his presence inside it comes in the form of a trace memory, a pseudo-presence through an iconic image which is flat and two-dimensional within the space of the stadium, while his presence outside the frame is invisible and yet at the center of attention: he seems to be everywhere and nowhere at the same time.

Moreover, his is the only face within this photograph whose far-removed, hardly discernible gaze is paradoxically directed towards Roberto Schmidt's lens and towards us now viewing the photograph. It is directed towards an out-of-frame space that is very different from the out-of-frame space of the ceremony. The characteristic of a front-faced portrait is that it allows a relation with the viewer, through the illusionary exchange of gazes. This is underlined by Martine Joly, when she argues that this pseudo face-to-face confrontation abolishes the space for a representation and creates the semblance of an interpersonal or dual relation, with an " $\mathrm{I}$ " that seems to be addressing a "you" in the there and then of a visual exchange. ${ }^{26}$ Barthes also ascribes the specific power of photography to this exchange of gazes: "For the Photograph has this powerwhich it is increasingly losing, the frontal pose being most often considered archaic nowadays - of looking me straight in the eye." ${ }^{27}$

But as Mandela' gaze is twice-removed because it is a photographed photograph, and with his face so obviously two-dimensional, so explicitly a mere, tiny image locked into its own space of representation, the illusion of a possible bridge or relation between the viewed and the viewer is easily broken. Mandela is only an image and as such he is Death personified, a phenomenon described by Barthes upon discovering a photograph of himself: "when I discover myself in the product of this operation, what I see is that I have become Total-Image, which is to say, Death in person; others - the Other - do not dispossess me of myself, they turn me, ferociously into an object, they put me at their mercy, at their disposal." ${ }^{28}$

\section{But Who is Really Taking the Pose?}

Let us briefly go back to the different types of contrasting poses in Schmidt's photograph, as things appear to be in fact slightly more complex and layered than stated so far. The four main characters are interestingly both natural and conventional, taken off-guard and set into a pose. Indeed, Michelle Obama was, in fact, not taking the pose in any way when she was accidentally captured in the classic pose of Renaissance portraiture: she was (for a fraction of a second) "spontaneously" or "naturally" conventional. As Sontag said of photography: "Life is not about significant details, illuminated aflash, fixed forever. Photographs are." ${ }^{29}$ The photographic process froze an unselfconscious Michelle Obama into a significant, culturally charged, symbolic and 
conventional pose. Maybe unconsciously taking this cue, commentators in the media launched into telling the story of a dignified Michelle Obama, sitting next to misbehaving politicians. ${ }^{30}$

As for the trio, on the one hand, they were taking the pose for their own selfie and adjusting their smiles in their mirroring screen so as to find a conventionally natural smile. ${ }^{31}$ But if they were deliberately posing for the sake of the smartphone, they were not taking the pose for Roberto Schmidt's camera that caught them off-guard: for once, as Schmidt argued on the AFP blog, no one was taking the pose, no one was complying to rules created by communication managers, in a ceremony lasting for several hours. According to him, the outcry his photograph triggered was in direct proportion to the control imposed on the image of head of states by communication professionals. ${ }^{32}$ And yet, though it seems a spontaneous gesture in the eyes of Schmidt, the trio is in fact taking the most newly and highly codified photographic poses of our times -a pose whose status within the visual regime and story-telling traditionnally associated to politicians' images hovers between contrasting interpretative poles. This interpretative tension around selfies made by politicians (and celebrities) stems from their "boundary-blurring" ${ }^{33}$ nature, allowing a combination of authenticity and contrivance, the ordinary and the exclusive, the public and the private. Despite the negative connotations associated to selfies, they "provide a way to reinforce, enlarge or break the frame of political activity as well as strengthen the traditional mechanism of political celebration (Marsch et al. 2010)." ${ }^{34}$ Schmidt's photograph is not a selfie but it forcefully frames this new pose alongside older, familiar regimes or modes of address, informing the viewer's gaze on the nature of such representations in themselves, by encapsulating multiple conventions in portraiture as well as several media-producing traditions like that of the official photo-journalist or that of the media-savvy politician turned amateur photographer. ${ }^{35}$

\section{Barack Obama and Selfies}

For politicians selfies have become part and parcel of what is expected from them on the campaign trail, as The New York Times explained in a 2015 article: "Candidates can now spend an hour - or sometimes two, as Senator Rand Paul did last month in New Hampshire-exhausting a line of eager selfie seekers." ${ }^{36}$ In that case, the selfie is mainly made by the "fan" with his/her own smartphone, for the purpose of feeding his own social media with "trophies": arguably, it is strictly speaking a fan's selfie (with a famous politician/ with the President) rather than a politician's selfie (with a supporter).$^{37}$ Of course, as pointed out by the same piece in The New York Times, politicians can indirectly take advantage of this free advertising: "Many campaigns say they are benefiting after posing for all those pictures. When shared on Facebook and Instagram, they can exponentially increase a candidate's visibility, spreading an authentic memento that helps extend the chatter around a rally beyond those who attended." 38

In the case of Danish Prime Minister Helle Thorning-Schmidt, her Facebook photo gallery ${ }^{39}$ clearly shows that she can be the one actually taking the picture with her own smartphone, a token of how commonly and widely accepted this practice for a leading politician is in Denmark. It may in turn explain why she would naturally take one of herself with Obama and Cameron at the ceremony, though the media storm around 
Roberto Schmidt's photograph maybe have led her never to upload it on any social media platform.

By contrast, Obama himself has hardly ever uploaded selfies he made with his own phone of himself with other people. Like others, he of course complies with selfietaking by fans and crowds, and there are numerous examples of people uploading "selfies with the president" they took with their own phones. But in April 2014, the White House nevertheless briefly considered banning selfies with President Obama altogether when it emerged that the selfie taken by Red Sox player David Ortiz (later revealed to be contracted to Samsung) during a ceremony for the team on the South Lawn was part of a marketing strategy of the company to promote the phone by retweeting the photo with a plug for its Galaxy Note $3 .{ }^{40}$

Interestingly, Obama has used the promise of a selfie with him as a way to support Organizing for Action. His communication team used official pictures taken by White House official photographer ${ }^{41}$ (most often Pete Souza) for the Flickr feed, showing visitors or supporters of Obama taking a selfie with him. They added colour filters on them along with superimposed messages for twitter posts" ${ }^{42}$ such as "Get your camera ready - this is your chance to meet President Obama" or "Bucket list: Take a selfie with the President (check). Have your moment with the President." ${ }^{43}$

Once more these are images of people taking "a selfie with Obama," not a selfie of Obama made by Obama as he is not holding the camera and will not immediately upload the resulting selfie on his own social media. What's more, the original photographs taken by White House official photographer Pete Souza were often taken many months, if not years, before Obama's team transformed them for communication purposes to promote totally different actions by the administration. For instance, the one in which Obama "poses for a picture at Magnolia's Deli \& Cafe during the college affordability bus tour in Rochester, NY" posted on Flickr dates back to August $22^{\text {nd }}$, 2013, whereas it was used in its redesigned format on his Twitter feed on June $1^{\text {st }}, 2016$ to remind people of the deadline for participating in Organizing for Action. In these cases, not only does Obama not actually take selfies, but he uses the traces of his participation in other people's selfies in disconnection with the instant of their making and for different communication purposes, breaking from the rule of immediate sharing normally implied by a selfie, and opening it up to other targets than just sharing oneself in a self-centered fashion.

31 To encourage young people to sign up for Obamacare before the February $15^{\text {th }}$ deadline, he featured in a Buzzfeed video entitled "Things Everybody Does But Does Not Talk About," a spinoff of a previous popular Buzzfeed called "7 Creepy Things Everybody Does." ${ }^{44}$ Obama is shown, while supposedly waiting for an interviewer, practicing his pitch in a mirror, especially the tricky pronunciation of the date of the deadline, which he repeats many times. "Boredom gives way to goofy behavior. He sticks his tongue out to check it. He poses in Joe Biden's shades. He gets out the selfie stick. And he shoots those invisible hoops." ${ }^{45} \mathrm{He}$ also "pretends to fail to dunk a cookie in a tall glass of milk. The cookie is too big. 'Thanks, Obama,' the president says, joining his fans online who use the phrase to mock his opponents who use the phrase to mock the president." Within an hour of its posting, the video had 1.6 million viewers. But again, strictly speaking, no actual Obama selfie was shown or used. taps into this new popular regime of visibility, with the purpose of federating 
participation in a common effort. ${ }^{46}$ The in-built virality of selfies based on their sharing on social media can only give extra leverage to Obama's communication strategy.

In September 2015, as a means to promote his environmental policies, Obama wielded a selfie stick in front of the receding Kenai glacier in Alaska with celebrity survivalist Bear Grylls. Newspapers showed pictures of Obama toting the stick, while the White House Instagram account finally posted an actual Obama selfie, bearing the amateur mistake of the camera-trigger finger obscuring part of it, which was ridiculed online as a "dad move." ${ }^{47}$ The Mail Online article includes Obama's selfie from the White House Instagram account and an arguably better-made selfie made by Bear Grylls for his own Twitter account. Other than the above example, the only selfie that appeared (on Obama's Facebook page in that case) is the one taken for the launching of Joe Biden's Instagram account. ${ }^{48}$

Overall, if Barack Obama certainly made large use of social media in his communication strategy, bringing the White House into the $21^{\text {st }}$ century, his use of selfies per se, remains relatively limited. Nathalie Heinich has argued that the mobile phone reconfigured access to visibility, making for nearly absolutely conflated status between producer, broadcaster and consumer of visibility. ${ }^{49}$ Yet, except for a few exceptions, President Obama never is the producer of a photograph of himself. He is always held in someone else's gaze, mobile phone lens and online media account, i.e the fan or the White House official photographer, Pete Souza. The latter pictures of Obama posing for selfies, taken by his official White House photographers-portraits of selfie makinghave been used by his communication managers not only in decontextualized ways but also for much wider purposes and conversations than what basic selfie-taking generally entails, such as for instance his support for Organizing for Action. The fact that Obama favours photographs in which he is held by someone else's gaze at a time when the general conflation of status is allowed by technology leads us back to the issue broached earlier of the gaze in portraits and self-portraits, an issue that requires further analysis in selfies.

\section{The Gaze in Selfies}

Both the selfie Obama took in Alaska and the one taken with Joe Biden give us a pretty good idea what the selfie taken by Helle Thorning-Schmidt would have looked like, had it been posted online: smiling faces squashed into a square or rectangular format. Selfies, as Jerry Saltz insisted,

are nearly always taken from within an arm's length of the subject. For this reason the cropping and composition of selfies are very different from those of all preceding self-portraiture. There is the near-constant visual presence of one of the photographer's arms, typically the one holding the camera. Bad camera angles predominate, as the subject is nearly always off-center. The wide-angle lens on most cell-phone cameras exaggerates the depth of noses and chins, and the arm holding the camera often looks huge..$^{50}$

36 A final characteristic is that a lot are front-faced images, with the protagonists not so much looking in the distance as peering at themselves in a tiny front-facing smartphone camera, that is to say in a mirror-like surface.

37 As mentioned beforehand, an exchange of gazes is what Barthes deemed one of the specific powers of photography. The model of an imaginary encounter between viewer 
and image was also an idea that Walter Benjamin insisted upon in his texts on photography. In his Little History of Photography, he quotes the way old Dauthendey talks about the first daguerreotypes of Hill:

We didn't trust ourselves at first [...] to look long at the first pictures he developed. We were abashed by the distinctness of these human images, and believed that the little tiny faces in the picture could see us, so powerfully was everyone affected by the unaccustomed clarity and the unaccustomed fidelity to nature of the first daguerreotypes. ${ }^{51}$

Interestingly enough, as Duttlinger underlines, Walter Benjamin's approach of photography in his various writings focuses on a number of portraits and what he says about them alternatively supports and contradicts his theoretical narrative about the disappearance or decline of the aura. Their frail auratic dimension is generally located in the sitter's face, and more specifically in his/her gaze. In "The Work of Art in the Age of Its Technological Reproducibility," he mentions early portrait photography, underlining that "in the fleeting expression of the human face, the aura beckons from early photographs for the last time." ${ }^{52}$ In Little History of Photography, he mentions again those early daguerreotypes: "There was an aura about them, a medium that lent fullness and security to their gaze even as it penetrated that medium. And once again the technical equivalent is obvious: it consists in the absolute continuum from brightest light to darkest shadow," due-quoting Orlik-to a "comprehensive illumination brought about by the long exposure times." ${ }^{53}$ Benjamin then examines a childhood photograph of Kafka, when "the reproducible collodium negative replaced the costly daguerreotype, paving the way for the large-scale commercial expansion of portrait photography," ${ }^{54}$ which then became more widely affordable. Enhancing reproducibility and the commercializing of studio portraits, these technical developments made for formulaic poses and conventional decor, and provided Benjamin with examples of "the de-individualizing effect of mechanical reproduction, namely the [...] triumph of normative representation." ${ }^{55}$ Yet, as Duttlinger shows, "although the Kafka portrait appears to support Benjamin's historical narrative about the loss of a photographic aura, this argument is immediately undermined when Benjamin describes Kafka's image as a pendant to its earlier, auratic predecessors," ${ }_{56}$ and he does so by focusing on Kafka's "immeasurable sad eyes." As Duttlinger argues, "Kafka's eyes [...] resist the picture's restrictive conventions. Their melancholy gaze invests the image with an element of individuality and immediacy which punctures its formulaic arrangement." ${ }^{57}$

For Benjamin, therefore, "the experience of the aura is centered on the gaze, that element which establishes a connection between viewer and sitter." ${ }^{58}$ This motif can still be found in his text "On Some Motifs in Baudelaire," even though the daguerreotype now seems divested of the inherent capacity to preserve an aura that he had granted it with in "Little History of Photography":

What was inevitably felt to be inhuman - one might say deadly - in daguerreotypy was the (prolonged) looking into the camera, since the camera records our likeness without returning our gaze. Inherent in the gaze, however, is the expectation that it will be returned by that on which it is bestowed. Where this expectation is met [...] there is an experience of the aura in all its fullness. [...] Experience of the aura thus arises from the fact that a response characteristic of human relationships is transposed to the relationship between humans and inanimate or natural objects. The person we look at, or who feels he is being looked at, looks at us in turn. To 
experience the aura of an object we look at means to invest it with the ability to look back at us. ${ }^{59}$ when he tried to "reimagine (something like) experience under the conditions of technologically mediated culture" ${ }^{10}$ and explored the effects of the commodification of images in an alienating modernity with the rise of industrial capitalism and standardization, it can nevertheless prove fruitful to link his analysis on the gaze to our own context, in which the selfie can be seen as a media commodity form, associated to a practice and shaped by political-economic power. ${ }^{61}$ With selfies, or more specifically with front-facing cameras, something in the gaze has been altered. Indeed, quoting Warfield, Jill Walker Rettberg in her book Seeing Ourselves Through Technology underlines one essential characteristic of selfie photography: the front-facing camera makes it possible to simultaneously see our reflection as in a mirror and record it, deleating and repeating the images until perfect control in self-representation is reached. ${ }^{62}$

Crially, in the case of front-faced selfies, the hidden presence of a "mirror" somewhat changes the nature of the fictional exchange of the gaze between the photographed and the viewer. Even if mirrors were used by painters when they produced their selfportraits, the making of the image took so long that the captured gaze never was set as it is in instantaneous photographs. In photographic portraits, as Rettberg said, there is much less control when holding an analogue camera up to a mirror, compared to a front-faced selfie. With selfies, the power of the illusion of an exchange of gazes through space and time is much weaker for viewers than in previous forms of portraits and self-portrait. When looking at a selfie, which is easily identified through its set, formal characteristics, the viewer must know that the gaze addressed to him/her is in fact closed up upon itself, locked on to a mirror vision of itself. As a viewer, I no longer think that the photographed face can see me, but that it is looking at itself on a mirroring-like surface. The horizon of the photographed person's gaze is no longer "absorbed in an ominous distance," ${ }^{63}$ and the photographed person's gaze no longer "meets" the viewer's eye in the same way. The bridging of the inner space of the representation and the out-of-frame space of perception is not only stripped of all its magic dimension and exposed as fake but has been replaced by a mirror-like, flat surface of fake depth. To go back to Benjamin's quote: "To experience the aura of an object we look at means to invest it with the ability to look back at us." In fact, a selfie's ability to look back at us is weakened in direct proportion to our knowledge that the photographed gaze it encapsulates is directed towards its own reflection, set at a mere arm's length. This shrinking of space and focus is powerfully rendered in Roberto Schmidt's photograph as argued earlier.

Still quoting Katie Warfield, Rettberg nevertheless claims that the viewer is more closely integrated in a selfie ${ }^{64}$ :

Although early photographers often used the camera as a barrier to protect them from the viewers in their self-portraits [...] the classic outstretched arm of the selfie taken with a front-facing smart phone camera very strongly includes the viewer in the space of the photograph. As Katie Warwick [sic] points out, the outstretched arm is like a (forced) embrace, placing the viewer between the face of the person photographed and the camera $[. . .]^{65}$

However, I would rather argue that the viewer is not placed "between the face of the person photographed and the camera"; the stretched arm is not embracing the viewer but clutching the screen/mirror as a looping extension of him/herself. So if the viewer 
is not excluded ${ }^{66} \mathrm{~s} /$ he is at best put in the position of the screen, if not behind it, which once again changes the nature of the fictional exchange of gazes. Arguably, for the taker of the selfie, the inhuman confrontation with the camera that was underlined by Benjamin is also transformed: the sitter who is also the photographer now exchanges a gaze... with him/herself, or his/her own mirror image, and only so when s/he takes the picture. Indeed, in taking the selfie, as Bertrand Naivin argues, the taker-cum-sitter's gaze appears to be skewed on the resulting image, this obliqueness being a trace of what I introduced above as the interruption in the exchange of gazes, between sitter and viewer:

When holding our device, [...] we are no longer looking at the lens that is taking the picture, but at the image itself, which appears on the screen at the same time as we "frame" it. Our gaze is skewed because its focus (the image) is itself at an angle with the lens. As a result, the gaze is "at an angle." It is no longer gazing outwardly and it is no longer gazing at the viewer of the received image. [...] But if it avoids us, the selfic "auto-gaze" never reaches itself either. For the selfie-taker is him/herself confronted to this "skewed" gaze that no longer focuses on the lens. S/He no longer is the artist who probes her/himself by focusing on her/his own gaze in the mirror, or who questions her/his photographic "self" by peering into the sole, black eye of her/his Cyclopean device. ${ }^{67}$

To conclude, Roberto Schmidt's press photograph contains, albeit unintentionally, a sort of lexicon of portraiture, iconically juxtaposing new forms (selfie-posture) with others that evoke cultural archives, such as the Renaissance female profile portrait or the front-faced memorial portrait. It also offers an image that captures the complex nature of the public and private images of public figures, and the issues of visibility in relation to power or fame. In the case of Obama, if he does favour images of him in the process of taking a selfie, garnering the authenticity and closeness the media affords, he nevertheless rarely uses actual selfies. He remains held by someone else's gaze rather than his own, which might be seen as a trace of his political power, making for a constant tension and distance between visibility and invisibility, access/intimacy and distance. Actual selfies might close the distance too much and cut off the crucial exchange of gazes, as he prefers keeping a primary political frame in his portraiture.

Furthermore, Schmidt's photograph is meta-photographical in at least two ways: it represents the act of taking a photograph, and it includes two photographs in its frame, one that is discreetly lying in its left margin (absent, iconic Mandela) and one that remains hidden and invisible on the mirror-like screen of a smartphone. The latter tool for widening visibility paradoxically remains an invisible screen, all the more so since Helle Thorning-Schmidt's selfie was never made public.

The multiplicity of gaze directions in Roberto Schmidt's photograph also foregrounds the more general issue of the nature of the selfie with its transformation of the connection between sitters, photographer and viewer, in terms of distance, focus and exchange of gazes. Current technological developments of front-faced cameras, allowing an unprecedented increase in reproducibility and exposure levels, have spread conventionality in photography with selfies, not only making for a normative, standardized or formulaic arrangement of the body posture, but also for a transformation of both the photographed's and the viewer's gaze, arguably weakening the potential experience of an aura for the viewer, and leading to a type of image (selfies) and skewed gaze which, as put forward by Naivin, breaks away from the traditions of (self)-portraits. 


\section{BIBLIOGRAPHY}

Barthes, Roland. La Chambre Claire. Paris: Gallimard, 1980; Camera Lucida: Reflections on Photography. Translated by Richard Howard. London: Vintage, 2000.

“Global Smartphone Shipments Top One Billion 'milestone'.” BBC news 28 January 2014. http:// www.bbc.com/news/business-25923404.

Benjamin, Walter. "Little History of Photography."; "The Work of Art in the Age of Its Technological Reproducibility”; “On Some Motifs in Baudelaire.” In Selected Writings, edited by Michael W. Jennings, Howard Eliand and Gary Smith. Translated by Rodney Livingstone and others. Cambridge, MA: Belknap, 1999.

Bellinger, Matthew. "Bae Caught Me Tweetin': On the Representational Stance of the Selfie." International Journal of Communication 9 (2015), 1806-1817.

Berger, Lynn. “Snapshots, or: Visual Culture' Clichés.” Photographies 4, no. 2 (2011), 175-190.

Beyer, Andreas. Portraits: A History. New York: Harry N. Abrams, 2003.

Bonnefoy, Yves. Préface à Lorne Campbell, La Peinture des portraits en Europe aux XIVe et XVIe siècles. Traduit par Dominique Le Bourg. Paris: Hazan, 1991.

Busetta, Laura \& Coladonato, Valerio. "Be Your Selfie: Identity, Aesthetics and Power in Digital Self-Representation.” Networking Knowledge 8, no. 6 Special Issue: Be Your Selfie (November 2015).

Campbell, Lorne. Renaissance Portraits: European Portrait Painting in the 14th, 15th and 16th centuries. New Haven [Conn.]: Yale University Press, 1990.

Collings, Beccy. "\#selfiecontrol: @CAZWELLnyc and the role of the ironic selfie in transmedia celebrity self-promotion.” Celebrity Studies 5, no. 4 (2014), 511-513.

Day, Elisabeth. “How Selfies Became a Global Phenomenon.” The Guardian, July 14, 2013. http:// www.theguardian.com/technology/2013/jul/14/how-selfies-became-a-global-phenomenon Drury, Flora. “'Glad this was the only Bear I met in the park': Obama jokes with Bear Grylls on an Alaskan glacier as he claims the melting ice represents 'doomsday' scenario of climate change. Mail Online, September 02, 2015. https://www.dailymail.co.uk/news/article-3219488/Glad-Bearmet-park-Obama-explorer-Bear-Grylls-hiking-Alaskan-wilderness-raise-awareness-climatechange.html.

Duttlinger, Carolin. "Walter Benjamin and the Aura of Photography." Poetics Today 29, no. 1 (Spring 2008), 79-101.

Ekman, Mattias \& Andreas Widholm. "Twitter and the Celebritisation of Politics." Celebrity Studies 5, no. 4 (2014), 518-520.

-_-. "Politicians as Media Producers." Journalism Practice 9, no. 1 (2015), 78-91.

Farci, Manolo \& Mario Orefice. "Hybrid Content Analysis of the Most Popular Politicians' Selfies on Twitter.” Networking Knowledge 8, no. 6 Special Issue: Be Your Selfie (November 2015).

Frosh, Paul. "The Gestural Image: The Selfie, Photography Theory, and Kinesthetic Sociability." International Journal of Communication 9 (2015), 1607-1628.

Gómez Cruz, Edgar \& Helen Thornham. "Selfies Beyond Self-Representation: the (Theoretical) F(r)ictions of a Practice. Journal of Aesthetics \& Culture 7, no. 1 (2015). 
Greig, Alex. "White House Set to BAN Selfies with the President Following Samsung Stunt with David Ortiz.” Mail Online, April 07 2014. http://www.dailymail.co.uk/news/article-2598427/ White-House-ban-selfies-President-following-Samsung-stunt.html.

Hall, James. "Pourquoi fait-on des autoportraits ?". In Autoportraits: De Rembrandt aux selfies, edited by Sylvie Ramond and Stéphane Paccoud. Lyon: Musée des beaux-arts; Cologne : Snoeck Verlagsgesellschaft, $2016,12-21$.

Hansen, Miriam. “Benjamin's Aura”. Critical Inquiry 34, no. 2 (Winter 2008): 336-375.

Heinich, Nathalie. De la visibilité. Excellence et singularité en régime médiatique. Paris: NRF Gallimard, 2012.

Iqani, Mehita \& Jonathan E. Schroeder. “\#selfie: Digital Self-Portraits as Commodity Form and Consumption Practice.” Consumption Markets \& Culture 19, no. 5 (2016), 405-415.

Joly, Martine. Introduction à l'analyse de l'image. Paris: Armand Colin, 2005.

-—-. L'image et les signes: Approche sémiologique de l'image fixe. Paris: Armand Colin, 2008.

McCarthy, Tom. “Obama breaks out the selfie stick." The Guardian 12 February 2015. https:// www.theguardian.com/us-news/2015/feb/12/obama-selfie-stick-buzzfeed-video-healthcare.

Miltneer, Kate M., Nancy K. Baym. "The Selfie of the Year of the Selfie: Reflections on a Media Scandal." International Journal of Communication 9 (2015), 1701-15.

Naivin, Bertrand. Selfie, Un nouveau regard photographique. Paris: L'Harmattan, 2016.

Nakamura, David and Greg Jaffe. "Obama and the rise of the selfie presidency." Washington Post, June 24, 2016. http://www.star-telegram.com/news/politics-government/article85778387.html.

Oxford Dictionary. blog.oxforddictionaries.com/press-releases/oxford-dictionaries-word-of-theyear-2013/

Pearson, Allison. "Mandela memorial selfie: If President Obama acts like this, don't blame teenagers." The Telegraph, December 11, 2013. https://www.telegraph.co.uk/news/worldnews/ nelson-mandela/10511140/Mandela-memorial-selfie-If-President-Obama-acts-like-this-dontblame-teenagers.html

Peraica, Ana. Culture of the Selfie: Self-Representation in Contemporary Visual Culture. Amsterdam: Institute of Network Cultures, 2017.

Peters, Jeremy W., Ashley Parker. "Facing a Selfie Election, Presidential Hopefuls Grin and Bear It." New York Times, July 04, 2015. https://www.nytimes.com/2015/07/05/us/politics/facing-aselfie-election-presidential-hopefuls-grin-and-bear-it.html?_r=0

Peterson, Bryan F. Learning to See Creatively: Design, Color and Composition in Photography. New York: Amphoto Books, 2003.

Rettberg, Jill Walker. Seeing Ourselves through Technology: How We Use Selfies, Blogs and Wearable Devices to See and Shape Ourselves. New York: Palgrave Macmillan, 2014.

Saltz, Jerry. “Art at Arm's Length: A History of the Selfie.” Vulture 26 (January 2014). http:// www.vulture.com/2014/01/history-of-the-selfie.html. Reprinted in Ego Update: A History of the Selfie, edited by Alain Bieber, 30-49. London: Koenig Books, 2016.

Selfie Scholar Network, The Selfie Research Network.

Senft, Theresa M. and Nancy K. Baym. "What Does the Selfie Say-Investigating a Global Phenomenon. Introduction.” International Journal of Communication 9 (2015), 1588-606. 
Schmidt, Roberto. “'Le' Selfie.” AFP blog. https://making-of.afp.com/le-selfie.

Soal, Judith. "Barack Obama and David Cameron pose for selfie with Danish PM." The Guardian, December 11, 2013. https://www.theguardian.com/world/2013/dec/10/nelson-mandela-worldleaders-selfie.

Sontag, Susan. On Photography. New York: Anchor Books Doubleday, 1973.

Visser, Josh. “Barack Obama's selfie with Danish prime minister leaves Twitter a-tweet about Michelle Obama 'soap opera”" National Post, December 10, 2020. https://nationalpost.com/news/ barack-obamas-selfie-with-danish-prime-minister-leaves-twitter-a-tweet-about-michelleobama-soap-opera.

Voorhees, Josh. "Photographer Tells the Story Behind the Obama Selfie, Laments We All Made a Big Deal About It." Slate, December 11, 2013. http://www.slate.com/blogs/the_slatest/ 2013/12/11/roberto_schmidt_afp_photog_tells_story_of_obama_selfie_pic_which_he_calls.html.

Wendt, Brooke. The Allure of the Selfie, Instagram and the New Self-Portrait. Network Notebooks \#8. Amsterdam: Institute of Network Cultures, 2014.

Wright, Ellen. "Watch the Birdie: The Star Economy, Social Media and the Celebrity Group Selfie." Networking Knowledge 8, no. 6 Special Issue: Be Your Selfie (November 2015).

\section{NOTES}

1. The outlets ranged from gossip websites such as Gawker, tweet feeds such as Michael Moore's, tabloids such as the Mirror or Mail Online in the UK, to broadsheets such as The New York Times or The Telegraph.

2. Theresa M. Senft and Nancy K. Baym, "What Does the Selfie Say-Investigating a Global Phenomenon. Introduction," International Journal of Communication 9 (2015), 1589.

3. In their methodological section, the authors explain they based their analysis on " 89 articles: 39 from the United States, 17 from the United Kingdom, and 33 from Denmark," with "37 articles from left-leaning outlets, 45 articles from right-leaning outlets, and 7 from news media in the center, [...] chosen from outlets in the top 50 news markets in the United States; all coverage from the United Kingdom and Denmark was included." Kate M. Miltner \& Nancy K. Baym. "The Selfie of the Year of the Selfie: Reflections on a Media Scandal," International Journal of Communication 9 (2015), 1704.

4. Schmidt himself explained, on the AFP blog page in which he was asked, after the Selfiegate, to write on the making-of of his picture, that he was sitting 150 meters opposite Obama and had decided to stick to each and all of the president's movements after he had made his speech and gone back to his seat, next to a woman Schmidt believed, at the time, to be one of obama's assistants. See the AFP blog page at https://making-of.afp.com/le-selfie.

5. See the AFP blog page at https://making-of.afp.com/le-selfie.

6. Martine Joly, Introduction à l'analyse de l'image (Paris: Armand Colin, 2005).

7. Martine Joly, L'image et les signes: Approche sémiologique de l'image fixe (Paris: Armand Colin, 2008), 158.

8. Handbooks detailing basic techniques for the composition of powerful visual images abound. For example, in photography: Bryan F. Peterson, Learning to See Creatively: Design, Color and Composition in Photography (New York: Amphoto Books, 2003).

9. Jerry Saltz, "Art at Arm's Length: A History of the Selfie," Vulture 26 (January 2014), accessed February 07, 2020, http://www.vulture.com/2014/01/history-of-the-selfie.html.

10. Miltner \& Baym, "The Selfie of the Year of the Selfie: Reflections on a Media Scandal”, 1706. 
11. "For taking and posing for this photograph, Thorning-Schmidt, Obama and Cameron were accused of conduct unbecoming of heads of state." Wright, Ellen. "Watch the Birdie: The Star Economy, Social Media and the Celebrity Group Selfie." Networking Knowledge 8, no. 6 Special Issue: Be Your Selfie (November 2015), 2.

12. Miltner \& Baym, "The Selfie of the Year of the Selfie: Reflections on a Media Scandal", 1707-08. They also refer to articles criticizing the sexism that the Danish Prime Minister was the target of: "A female prime minister talking to a male president is presumed to be flirting, and he is presumed to be flirting back" (para. 1). The Danes in particular were offended by these narratives and devoted almost a third of their total coverage of the event to dissecting race and gender bias within the U.S. and British media. An editorial in Politiken argued that ThorningSchmidt had been "slut-shamed" and detailed the litany of absurdly misogynist and sexualized commentary that had been leveled at her.", 1708-1709.

13. The paper will later discuss how selfie-taking has nevertheless also become a strategy by politicians in general and obama in particular, making social media part and parcel of their communication tools. Miltner and Baym already picked on the way the media coverage of the photograph focused on the growing use of social media in politics: "Obama and ThorningSchmidt were frequently associated with social media, the implication being that the "Selfie Presidency" (Graham, 2013, para. 7) and the "Prime Minister of the Facebook generation" (Lillelund, 2013, para. 3) are too preoccupied with popularity and image to do their jobs properly. [...] These concerns about the disintegrating boundaries between politicians and pop culture are not new. Handwringing about "celebrity politicians" reached a fever pitch in the United Kingdom in the early 2000s (Street, 2004)." Miltner \& Baym, "The Selfie of the Year of the Selfie: Reflections on a Media Scandal," 1707.

14. Josh Voorhees, "Photographer Tells the Story Behind the Obama Selfie, Laments We All Made a Big Deal About It." Slate, December 11, 2013, accessed February 04, 2020, http://www.slate.com/ blogs/the_slatest/2013/12/11/

roberto_schmidt_afp_photog_tells_story_of_obama_selfie_pic_which_he_calls.html.

15. Lorne Campbell, Renaissance Portraits: European Portrait Painting in the 14th, 15 th and $16^{\text {th }}$ centuries (New Haven [Conn.]: Yale University Press, 1990).

16. James Hall, "Pourquoi fait-on des autoportraits?". In Autoportraits: De Rembrandt aux selfies. (Edited by Sylvie Ramond and Stéphane Paccoud. Lyon: Musée des beaux-arts; Cologne : Snoeck Verlagsgesellschaft, 2016), 12-21.

17. Andreas Beyer, Portraits: A History (New York: Harry N. Abrams, 2003).

18. In his preface to the French translation of Lorne Campbell's book on Renaissance Portraits, French poet Yves Bonnefoy insists on the way portraits refer to death. His comments in French run: "Le portrait réfère à la mort. [...] ce qui est unique, dans la vie comme nous l'avons, transitoire, est destiné à périr et par tous ses signes le laisse entendre. Cet apparaître est un disparaître ; et ne peut être observé, par le sculpteur ou le peintre, qu'avec les yeux de sa propre précarité. [...] Tout portrait réfère à la mort, et c'est dire aussi bien, c'est avoir à dire aussitôt qu'il suppose active une dimension de la transcendance." Preface by Yves Bonnefoy for Lorne Campbell, La Peinture des portraits en Europe aux XIVe et XVIe siècles. Translated by Dominique Le Bourg (Paris: Hazan, 1991).

19. See for instance "Michelle, who was dignity personified in black lace" in Allison Pearson, "Mandela memorial selfie: If President Obama acts like this, don't blame teenagers." The Telegraph, December 11, 2013, accessed June 4, 2020, https://www.telegraph.co.uk/news/ worldnews/nelson-mandela/10511140/Mandela-memorial-selfie-If-President-Obama-acts-likethis-dont-blame-teenagers.html. Or "Michelle Obama maintained her dignity and refused to join in the antics." in Judith Soal, "Barack Obama and David Cameron pose for selfie with Danish PM." The Guardian, December 11, 2013, accessed June 4, 2020, https://www.theguardian.com/world/ 2013/dec/10/nelson-mandela-world-leaders-selfie. 
20. See for instance da Fabriano's Adoration of the Magi (1423), Uffizi Gallery, Florence and Botticelli's Adoration of the Magi (circa 1476), Uffizi Gallery, Florence.

21. Paul Frosh defines the selfie as a gestural image and explains the outstretched arms participate to the "deictic movement of the body", reminding "deixis is the pointing finger, directing attention onto a present object". "The Gestural Image: The Selfie, Photography Theory, and Kinesthetic Sociability." International Journal of Communication 9 (2015), 1607-1628. The extended arms also create as a reflexive loop, directing attention onto the faces of the trio.

22. See Manolo Farci \& Mario Orefice. "Hybrid Content Analysis of the Most Popular Politicians' Selfies on Twitter." Networking Knowledge 8, no. 6 Special Issue: Be Your Selfie (November 2015), 1-25, and Lynn Berger, “Snapshots, or: Visual Culture' Clichés." Photographies 4, no. 2 (2011), 175-190.

23. See Jill Walker Rettberg, Seeing Ourselves through Technology: How We Use Selfies, Blogs and Wearable Devices to See and Shape Ourselves (New York: Palgrave Macmillan, 2014), 9; and Senft \& Baym, "What Does the Selfie Say-Investigating a Global Phenomenon. Introduction.", 1595. For a definition of selfie, see Oxford Dictionaries at https://www.lexico.com/en/definition/selfie: "a photograph that one has taken of oneself, typically one taken with a smartphone or webcam and uploaded to a social media website". Academic approaches list further visual markers (face, gaze, mirror, angle), question its relation to self-portraits in art history, insist on the essential combination of text and image, analyze the language of the attached tweets (such as first-person phrasing, tense), underline its personal reflexivity and self-consciousness, or its socio-technical and performative dimension beyond the representational image as well as the power relations it sets and the communication responses it invites through visual chat (re-tweets, response selfies...) and so on. See Bellinger, "Bae Caught Me Tweetin': On the Representational Stance of the Selfie." International Journal of Communication 9 (2015), 1806-1817; Farci \& Orefice, "Hybrid Content Analysis of the Most Popular Politicians' Selfies on Twitter."; Frosh, "The Gestural Image"; Gómez Cruz \& Thornham, "Selfies Beyond Self-Representation: the (Theoretical) F(r)ictions of a Practice. Journal of Aesthetics \& Culture 7, no. 1 (2015), 1-10, Peraica, Culture of the Selfie: Self-Representation in Contemporary Visual Culture. (Amsterdam: Institute of Network Cultures, 2017) and many others.

24. Saltz, "Art at Arm's Length."

25. Susan Sontag, On Photography (New York: Anchor Books Doubleday, 1973), 37-8.

26. Joly, L'image et les signes, 121.

27. Roland Barthes, Camera Lucida: Reflections on Photography, trans. Richard Howard (London: Vintage, 2000), 111.

28. Barthes, Camera Lucida, 14.

29. Sontag, On Photography, 81.

30. "Obama, Cameron, and Thorning-Schmidt let their game faces slip by smiling and laughing when they were supposed to be somber and dignified [...] This viewpoint was consistent across the coverage in all three nations." Miltner \& Baym, "The Selfie of the Year of the Selfie: Reflections on a Media Scandal," 1706-1707. Some coverage challenged this narrative, adding photographs showing "Michelle was also caught in conversation with Thorning-Schmidt herself, confounding those always eager to comment on the first marriage" (Soal), or explaining "The later photo shows the Obamas have switched seats, with the first lady sitting next to the Danish prime minister and the president looking ahead sombrely" (Visser).

31. See Barthes: "once I feel myself observed by the lens, everything changes: I constitute myself in the process of 'posing', I instantaneously make another body for myself, I transform myself in advance into an image" (Barthes, Camera Lucida, 10).

32. AFP blog page at https://making-of.afp.com/le-selfie.

33. Beccy Collings, "\#selfiecontrol: @CAZWELLnyc and the role of the ironic selfie in transmedia celebrity self-promotion." Celebrity Studies 5, no. 4 (2014), 5112. Also Ellen Wright, "Watch the 
Birdie: The Star Economy, Social Media and the Celebrity Group Selfie." Networking Knowledge 8, $\mathrm{n}^{\circ} 6$ Special Issue: Be Your Selfie (November 2015), 4.

34. Farci \& Orefice, "Hybrid Content Analysis of the Most Popular Politicians' Selfies on Twitter.", 3-4.

35. Many papers focus on the impact of social media in politics and communication strategies. See for instance Busetta \& Coladonato, "Be Your Selfie: Identity, Aesthetics and Power in Digital Self-Representation.” Networking Knowledge 8, no. 6 Special Issue: Be Your Selfie (November 2015); Farci \& Orefice, "Hybrid Content Analysis of the Most Popular Politicians' Selfies on Twitter." or Ekman \& Widholm, "Twitter and the Celebritisation of Politics." Celebrity Studies 5, no. 4 (2014).

36. Jeremy W. Peters and Ashley Parker, "Facing a Selfie Election, Presidential Hopefuls Grin and Bear It," New York Times, July 04, 2015 https://www.nytimes.com/2015/07/05/us/politics/facinga-selfie-election-presidential-hopefuls-grin-and-bear-it.html?_r=0.

37. For instance, in their sample, Farci and Orefice show the scarcity of selfies taken directly by politicians: "We discovered that out of a total 171 sampled photos, 149 images were selfies taken by members of the public, who attached these images to self-produced tweets mentioning politicians' twitter accounts in their body-text (e.g. 'I'm honored to take a selfie with the great @David_Cameron' or 'I'm really proud to announce that the person close to me is @algore in person!!'). Only 22 were actually produced by politicians or directly came from their official Twitter profiles." Farci \& Orefice. "Hybrid Content Analysis of the Most Popular Politicians'Selfies on Twitter.", 8.

38. Ibid.

39. A quick look at the photo gallery of her Facebook page brings up numerous images of Helle Thorning-Schmidt taking selfies or posing for selfies. For instance on photographs dated June 14, 2015, accessed February 07, 2020, https://www.facebook.com/hellethorningschmidt/photos/a. 10150203759123852.381200.11060438851/10153938115178852/?type=3\&theater, or June 03, 2015, accessed February 07, 2020, https://www.facebook.com/hellethorningschmidt/photos/a. $10152783200618852.1073741845 .11060438851 / 10153912297463852 /$ type $=3 \&$ theater, or May $1^{\text {st }}$, 2014, accessed February 07, 2020, https://www.facebook.com/hellethorningschmidt/photos/a. 10152784200433852.1073741846.11060438851/10152784201198852/?type=3\&theater).

40. Alex Greig, "White House set to BAN selfies with the President following Samsung stunt with David Ortiz." Mail Online, April 07 2014, accessed February 06, 2020, http://www.dailymail.co.uk/ news/article-2598427/White-House-ban-selfies-President-following-Samsung-stunt.html. David Nakamura and Greg Jaffe, "Obama and the rise of the selfie presidency." Washington Post, June 24, 2016, accessed February 06, 2020, http://www.star-telegram.com/news/politics-government/ article85778387.html.

41. These photographs can be found on Obama's official White House flickr feed. Out of more than 6,600 photographs, only ten capture Barack Obama in the process of posing for someone's selfie-shot. The following links give access to three of those that were turned into promotional calls for Organizing for Action: https://www.flickr.com/photos/obamawhitehouse/12241810654/ in/photolist-jDLtNW; https://www.flickr.com/photos/obamawhitehouse/20283628443/in/ photolist-wUoU4M; $\quad$ https://www.flickr.com/photos/obamawhitehouse/14081505711/in/ photolist-nskp4e. The other photographs showing Obama taking the pose for selfies or just being caught by a selfie taker can be found on Flickr at P102715LJ-0329; P012115PS-0201; P092214PS-0854; P120314PS-07875; P061014PS-0783; P052514PS-0866; P042710PS-0751.

42. These Twitter pictures can be found here: https://twitter.com/BarackObama/status/ 738155058177576960/photo/1; https://twitter.com/BarackObama/status/646435202412101632/ photo/1; https://twitter.com/BarackObama/status/581535059003318272/photo/1

43. Accessed February 06, 2020, https://twitter.com/BarackObama/status/581535059003318272/ photo/1. They are part of a whole series of pictures on Twitter in which the promise of a meeting with the President entails many other things than selfie-taking, like "a casual stroll" with him, a 
chance "to talk about anything-even compare jump shots," get "free flight, free hotel" or share a moment "because presidential hugs are the best hugs".

44. Accessed 06 February, 2020, http://www.dailymotion.com/video/x2h2vrg.

45. Tom McCarthy, "Obama breaks out the selfie stick," The Guardian 12 February 2015. https:// www.theguardian.com/us-news/2015/feb/12/obama-selfie-stick-buzzfeed-video-healthcare

46. In their analysis of the 15 selfies of Obama they found, Farci and Orefice come to the conclusion that "Al Gore and Obama use selfies to strengthen the relationship between their public image and the political interest for public affairs," to "reinforce their primary political frame." Farci \& Orefice, "Hybrid Content Analysis of the Most Popular Politicians'Selfies on Twitter.", 11-12.

47. Flora Drury, “'Glad this was the only Bear I met in the park': Obama jokes with Bear Grylls on an Alaskan glacier as he claims the melting ice represents 'doomsday' scenario of climate change. Mail Online, September 02, 2015, accessed February 04, 2020, https://www.dailymail.co.uk/news/ article-3219488/Glad-Bear-met-park-Obama-explorer-Bear-Grylls-hiking-Alaskan-wildernessraise-awareness-climate-change.html.

48. It was posted on 17 April 2014, with the comment "Welcome to Instagram, Mr VicePresident," accessed February 05, 2020, https://www.facebook.com/barackobama/photos/a. 53081056748.66806.6815841748/10152248471021749/?type=3\&theater.

49. Nathalie Heinich, De la visibilité. Excellence et singularité en régime médiatique (Paris: NRF Gallimard, 2012), 121.

50. Saltz, "Art at Arm's Length."

51. Walter Benjamin, Selected Writings, trans. Rodney Livingstone and others (Cambridge [Mass.]: Belknap, 1999), 512.

52. Benjamin, Selected Writings, 259.

53. Benjamin, Selected Writings, 515-17.

54. Carolin Duttlinger, "Walter Benjamin and the Aura of Photography," Poetics Today 29, no. 1 (Spring 2008), 87.

55. Duttlinger, "Walter Benjamin,” 91.

56. Duttlinger, "Walter Benjamin," 88.

57. Duttlinger, "Walter Benjamin," 90.

58. Duttlinger, "Walter Benjamin," 95.

59. Benjamin, Selected Writings, 338.

60. Miriam Hansen. “Benjamin's Aura”. Critical Inquiry 34, No. 2 (Winter 2008), 339.

61. "Selfies are media commodities in two ways. Firstly, all users of Facebook and Instagram (and similar applications) are enrolled, knowingly or not, in a corporate owned service, which is ultimately profit oriented ans sells advertising space [...]. Apart from an expressive consumer practice, we can think of the selfie as a branding tool, a market research technique, and a social media content generator. Secondly, the self-portraits turn the image of the self into a commodity that is made public and consumable by others, projecting personal images into collective space and literally 'sharing' very widely self-produced messages. Considering the aesthetic properties of selfies, it becomes clear that they are a unique visual genre with particular forms of use and exchange value." Iqani, Mehita \& Jonathan E. Schroeder. "\#selfie: digital self-portraits as commodity form and consumption practice." Consumption Markets \& Culture 19, $\mathrm{n}^{\circ} 5$ (2016), 410-411.

62. Katie Warfield notes that this is "the first time we can use a device to simultaneously see our reflection and record it. Mirrors allowed us to see our own reflection, but not to record it. Cameras allowed us to record our own image, but until the digital display and front-facing camera of the smartphone, they did not allow us to see our face as we pressed the shutter [...]. That, and the ease and inexpense of deleting digital images and taking new ones, allow us to control the way we are represented to a far greater degree than in a photobooth or holding an 
analogue camera up to a mirror." Jill Walker Rettberg, Seeing Ourselves through Technology: How We Use Selfies, Blogs and Wearable Devices to See and Shape Ourselves (New York: Palgrave Macmillan, 2014), 11-12.

63. Benjamin, Selected Writings, 510 .

64. Paul Frosh also makes this point arguing the outstretched arm is an invitation to the distant viewer. He also compares the smartphone to a pocket makeup-mirror but does not analyze the differing nature of the photographer's gaze due to the angle with the lens. See Frosh, "The Gestural Image."

65. Rettberg, Seeing Ourselves, 9.

66. Ana Peraica describes mobile phone culture creating an imprisonment within the media loop, "denying our own position as separate agents in the process of communication. As tools become smaller, the space for representing others, even non-present audience also miniaturizes, and the subject withdraws inside a small universe, as small as a tiny birdcage." Ana Peraica, Culture of the Selfie, 44.

67. Bertrand Naivin, Selfie, Un nouveau regard photographique (Paris: L'Harmattan, 2016), 136-37, 140.

\section{ABSTRACTS}

This paper focuses on an iconological analysis of Roberto Schmidt's photograph of Danish Prime Minister Helle Thorning-Schmidt taking a selfie with U.S. President Barack Obama and U.K. Prime Minister David Cameron during late President Nelson Mandela's memorial service on December 10th, 2013, at the First National Bank Stadium in Soweto. This analysis shows the compositional strength of the photograph and argues that part of its power rests in the way it contains, albeit unintentionally, a sort of lexicon of portraiture, iconically juxtaposing new forms (selfie-posture) with others that evoke cultural archives, such as the Renaissance female profile portrait or the front-faced memorial portrait.

Schmidt's photograph also offers an image that captures the complex nature of the public and private images of public figures, and the issues of visibility in relation to power or fame. This leads to comments on Obama's use of selfies in his communication strategy during his time at the White House.

Finally, the multiplicity of gaze directions in Roberto Schmidt's photograph as well as its metaphotographical dimension opens up a discussion on the more general issue on the nature of the selfie per se, with its transformation of the connection between sitters, photographer and viewer, in terms of distance, focus and exchange of gazes. Current technological developments of frontfaced cameras, allowing an unprecedented increase in reproducibility and exposure levels, have spread conventionality in selfie photography, not only making for a normative, standardized or formulaic arrangement of the body posture, but also for a transformation of both the photographed's and the viewer's gaze, arguably weakening the potential experience of an aura for the viewer, and leading to a type of image (selfies) and skewed gaze which, as argued by Bertrand Naivin, breaks away from the traditions of (self-) portraits. 
INDEX

Keywords: selfie, self-portrait, portraiture, iconography, Barack Obama

\section{AUTHOR}

\section{BÉATRICE TROTIGNON}

Béatrice Trotignon is an Associate Professor at the Université Paris-Dauphine-PSL and is a member of the LARCA research unit (UMR8225) at Université de Paris. Part of her teaching involves a course on Pop Art and her research focuses on contemporary American poetry, literature, and art history.

Université Paris Dauphine, LARCA, CNRS, F-75013 Paris, France

beatrice.trotignon@dauphine.psl.eu 